\title{
Molecular characteristics of antibiotic-resistant Escherichia coli and Klebsiella pneumoniae strains isolated from hospitalized patients in Tehran, Iran
}

\author{
Javad Yasbolaghi Sharahi ${ }^{1}$, Ali Hashemi ${ }^{1 *} \mathbb{B}$, Abdollah Ardebili $^{2,3}$ and Sara Davoudabadi ${ }^{1}$
}

\begin{abstract}
Background: We evaluated the distribution of carbapenem and colistin resistance mechanisms of clinical E. coli and K. pneumoniae isolates from Iran.

Methods: 165 non-duplicate non-consecutive isolates of $K$. pneumoniae and E. coli were collected from hospitalized patients admitted to Iran's tertiary care hospitals from September 2016 to August 2018. The isolates were cultured from different clinical specimens, including wound, urine, blood, and tracheal aspirates. Antibiotic susceptibility testing was performed by disc diffusion and microdilution method according to the Clinical and Laboratory Standards Institute (CLSI) guideline. The presence of extended spectrum $\beta$-lactamases (ESBLs) genes, carbapenemase genes, as well as fosfomycin resistance genes, and colistin resistance genes was also examined by PCR-sequencing. The ability of biofilm formation was assessed with crystal violet staining method. The expression of colistin resistance genes were measured by quantitative reverse transcription-PCR (RT-qPCR) analysis to evaluate the association between gene upregulation and colistin resistance. Genotyping was performed using the multi-locus sequencing typing (MLST).

Results: Colistin and tigecycline were the most effective antimicrobial agents with $90.3 \%$ and $82.4 \%$ susceptibility. Notably, 16 (9.7\%) isolates showed resistance to colistin. Overall, 33 (20\%), 31 (18.8\%), and 95 (57.6\%) isolates were categorized as strong, moderate, and weak biofilm-producer, respectively. Additionally, bla $a_{\mathrm{TEM}}, b / a_{\mathrm{SHV}}, b / a_{\mathrm{CTX}-\mathrm{M}}, b / a_{\mathrm{NDM}-1}$, bla $a_{\mathrm{OXA}-48 \text {-like }}$ and bla $a_{\mathrm{NDM}-6}$ resistance genes were detected in 98 (59.4\%), 54 (32.7\%), 77 (46.7\%), 3 (1.8\%), 17 (10.30\%) and $3(1.8 \%)$ isolates, respectively. Inactivation of $\mathrm{mgrB}$ gene due to nonsense mutations and insertion of IS elements was observed in 6 colistin resistant isolates. Colistin resistance was found to be linked to upregulation of $p m r A-C$, pmrk, phoP, and phoQ genes. Three of bla $a_{\mathrm{NDM}-1}$ and 3 of bla $a_{\mathrm{NDM}-6}$ variants were found to be carried by IncL/M and IncF plasmid, respectively. MLST revealed that b/a $a_{\mathrm{NDM}}$ positive isolates were clonally related and belonged to three distinct clonal complexes, including ST147, ST15 and ST3299.
\end{abstract}

Conclusions: The large-scale surveillance and effective infection control measures are also urgently needed to prevent the outbreak of diverse carbapenem- and colistin-resistant isolates in the future.

Keywords: Klebsiella pneumoniae, Escherichia coli, Antibiotic resistance genes, Carbapenem, Colistin

*Correspondence: ali.hashemi@sbmu.ac.ir; Hashemi1388@yahoo.com ${ }^{1}$ Department of Microbiology, School of Medicine, Shahid Beheshti University of Medical Sciences, Tehran, Iran

Full list of author information is available at the end of the article

\section{Background}

Enterobacteriaceae are opportunistic pathogens that cause severe nosocomial infections, including urinary tract infections (UTIs), bloodstream infections,

c) The Author(s) 2021. This article is licensed under a Creative Commons Attribution 4.0 International License, which permits use, sharing, adaptation, distribution and reproduction in any medium or format, as long as you give appropriate credit to the original author(s) and the source, provide a link to the Creative Commons licence, and indicate if changes were made. The images or other third party material in this article are included in the article's Creative Commons licence, unless indicated otherwise in a credit line to the material. If material is not included in the article's Creative Commons licence and your intended use is not permitted by statutory regulation or exceeds the permitted use, you will need to obtain permission directly from the copyright holder. To view a copy of this licence, visit http://creativeco mmons.org/licenses/by/4.0/. The Creative Commons Public Domain Dedication waiver (http://creativecommons.org/publicdomain/ zero/1.0/) applies to the data made available in this article, unless otherwise stated in a credit line to the data. 
abdominal infections, and ventilator-associated pneumonia [1, 2]. Escherichia coli and Klebsiella pneumoniae are two important members of Enterobacteriaceae that have the ability to develop resistance to various classes of antibiotics. Nowadays, carbapenem antibiotics are recommended as the last-line therapy for MDR strains of K. pneumoniae and E. coli infections [1,3]. However, increasing rate of resistance to carbapenems has complicated the treatment process and led to untreatable hospital infections [1, 4]. Resistance to carbapenems in Enterobacteriaceae is mainly mediated by the production of carbapenem-hydrolyzing enzymes (carbapenemases), among which Klebsiella pneumoniae carbapenemase (KPC), metallo- $\beta$-lactamases (VIM, IMP, NDM), and OXA-48 type of enzymes are the most common. Mobile genetic elements, including plasmids, transposons, and integrons are involved in the dissemination of related encoding genes [5-7].

New Delhi metallo- $\beta$-lactamase-1 (NDM-1) is one of the most important type of carbapenemases in carbapenem-resistant Enterobacteriaceae (CRE) [8, 9]. The $b l a_{\mathrm{NDM}^{-}}$-positive strains are usually resistant to most antimicrobial agents in addition to $\beta$-lactams due to the co-existence of other resistance mechanisms [10]. Such resistant strains have known as the leading cause of infections associated with high mortality worldwide, representing a significant challenge for clinical management and public health [11]. Under these conditions, clinicians rely on a few alternative antibiotics e.g., colistin, fosfomycin, and tigecycline to treat infections caused by CRE $[1,12]$.

The old polymyxin antibiotic colistin (i.e., polymyxin E) is now recommended as the last choice for treatment of MDR Gram-negative bacteria, especially CRE infections [13]. The recent increase in the use of colistin in clinical practice, accompanied by its unbridled use in agriculture, have contributed to the rapid dissemination of resistance [14]. Colistin resistance is caused by decreases in the net negative charge of the outer membrane, loss of lipid A, or efflux pumps and plasmid-encoded $m c r$ genes [15]. The $m c r-1$ gene uses a target site modification mechanism to protect bacteria from the action of colistin. The $m c r$ gene is observed on transferable plasmid and encodes an enzyme called phosphatidylethanolamine transferase which transfers the phosphatidylethanolamine residue to lipid A [16].

The main purpose of this study was to evaluate the antimicrobial resistance patterns and molecular mechanisms of carbapenem and colistin resistance among the clinical isolates of E. coli and K. pneumoniae from hospitalized patients admitted to tertiary care hospitals in Tehran, Ahwaz, Kashan, Tabriz, Sari, Gorgan, Birjand and Babol. In addition, the ability of biofilm production as well as clonal and genetic diversity of isolates were examined.

\section{Methods \\ Ethical statement}

This study was approved by the Ethics Committee of Shahid Beheshti University of Medical Sciences "IR.SBMU. MSP.REC.1397. 629". In order to maintain patients confidentiality participants were anonymous and no personal information was collected or included in the study.

\section{Bacterial isolates}

K. pneumoniae and E. coli isolates were collected from hospitalized patients infected in Iran hospitals from September 2016 to August 2018. The isolates were cultured from different clinical specimens, including wound, urine, blood, and tracheal aspirates. Each isolate was identified at species level based on the biochemical reactions, including reaction on $\mathrm{SH} 2 /$ indole/motility (SIM) medium, triple sugar iron (TSI) agar, urease production on urea agar, growth on Simmons'citrate agar medium, methyl red/Vogues-Proskauer (MR/VP), and ornithine decarboxylase (OD) test [17]. All isolates were stored in tryptic soy broth (TSB) tube with $20 \%$ glycerol at $-70{ }^{\circ} \mathrm{C}$.

\section{Antimicrobial susceptibility testing}

Antimicrobial susceptibility of all E. coli and K. pneumoniae isolates was determined by the Kirby-Bauer disk diffusion method on Cation-Adjusted Mueller Hinton agar (Merck, Germany) and interpreted as recommended by the Clinical and Laboratory Standards Institute (2018 CLSI breakpoints) or Food and Drug Administration (FDA) breakpoints guidelines (for tigecycline) [18, 19]. Antibiotic discs used were as follow: penicillins [piperacillin (PIP, $100 \mu \mathrm{g}$ )], $\beta$-lactam/ $\beta$-lactamase inhibitor combinations [piperacillin/tazobactam (PTZ, 100/10 $\mu \mathrm{g}$ )], cephems [ceftazidime (CAZ, $30 \mu \mathrm{g})$, cefotaxime (CTX, $30 \mu \mathrm{g}$ ), cefepime (FEP, $30 \mu \mathrm{g}$ ), cefpodoxime (CPD, $30 \mu \mathrm{g})$ ], monobactams [aztreonam (ATM, $30 \mu \mathrm{g})$ ], carbapenems [imipenem (IPM, $10 \mu \mathrm{g}$ ), meropenem (MEM, $10 \mu \mathrm{g}$ ), ertapenem (ETP, $10 \mu \mathrm{g}$ ), doripenem (DOR, $10 \mu \mathrm{g}$ )], aminoglicosides [gentamicin(GEN,10 $\mu \mathrm{g}$ )], Amikacin (AK, $30 \mu \mathrm{g})$ ], Fluoroquinolones [ciprofloxacin (CIP, $5 \mu \mathrm{g})$ ], inhibitors [trimethoprim-sulfamethoxazole (TS, $2.5 \mu \mathrm{g}$ )], fosfomycins [fosfomycin/trometamol (FOT, 200 $\mu \mathrm{g}$ )], tigecycline (TGC, $15 \mu \mathrm{g}$ ), and nalidixic acid (NA, $30 \mu \mathrm{g}$ ), (Mast Group, Merseyside, UK). The minimum inhibitory concentrations (MICs) of seven antibiotics, including imipenem, meropenem, ceftazidime, cefotaxime, cefepime, ciprofloxacin, and colistin were determined by broth microdilution method on Cation-Adjusted Mueller Hinton broth (Merck, Germany), and the results were analyzed according to the CLSI guidelines [18]. The 2016 
EUCAST breakpoints were used (available at http:// www.eucast.org/clinical_breakpoints/) for colistin. The antibiotic powders were purchased from Sigma-Aldrich (St. Louis, MO, USA). E. coli ATCC 25922 was used as a quality control strain for disk diffusion and MIC results.

The CDC and the European Centre for Disease Prevention and Control (ECDC) have jointly developed definitions for multidrug-resistant (MDR), extensively drug-resistant (XDR) and pandrug-resistant (PDR) bacteria. MDR was defined as acquired non-susceptibility to at least one agent in three or more antimicrobial categories, XDR was defined as non-susceptibility to at least one agent in all but two or fewer antimicrobial categories and PDR was defined as non-susceptibility to all agents in all antimicrobial categories.

\section{Phenotypic detection of $\beta$-lactamases}

Detection of ESBLs was tested for all the isolates by combination disc diffusion test (CDDT) containing ceftazidime (CAZ) and cefotaxime (CTX) with CAZ $30 \mu \mathrm{g}$ + clavulanic acid $10 \mu \mathrm{g}$ and CTX $30 \mu \mathrm{g}+$ clavulanic acid $10 \mu \mathrm{g}$ per disc (Mast Group, Merseyside, UK). K. pneumoniae ATCC 700,603 and E. coli ATCC 25,922 were used as positive and negative controls for ESBL production, respectively [22].

\section{Phenotypic detection of metallo $\beta$-lactamases}

Combined disk diffusion test (CDDT) was performed for identification of MBLs by imipenem and meropenem (Mast Group, Merseyside, UK) alone and in combination with EDTA [20]. Pseudomonas aeruginosa ATCC 27853 and P. aeruginosa PA40 (Accession number: KM359725) were used as negative and positive controls for MBL production, respectively.

\section{Screening for carbapenemase production}

The Carba NP test was performed for the detection of carbapenemase activity in isolates as described previously $[21,22]$.

\section{Biofilm formation assay}

Assessment of biofilm formation was performed by the colorimetric microtiter plate assay in triplicates [20, 21]. Overnight cultures of bacterial isolates were suspended in tryptic soy broth (TSB) (Merck-Germany) at $37^{\circ} \mathrm{C}$. Then, $200 \mu \mathrm{L}$ bacterial suspension with turbidity of $0.5 \mathrm{McF}$ arland standard were transferred into the sterile 96-well polystyrene microplates (JET Biofil, Guangzhou, China). TSB without bacteria was used as negative control. After $24 \mathrm{~h}$ of incubation at $37^{\circ} \mathrm{C}$, each well was rinsed three times with phosphate buffered saline (PBS, $\mathrm{pH}$ 7.3) to remove any non-adherent cells. Fixation and staining the adherent cells were performed by methanol and $1 \%$ crystal violet (Merck, Germany). Then, plates were gently rinsed off with PBS and destained by $33 \%$ glacial acetic acid and finally OD of each well were measured at $492 \mathrm{~nm}$. The criteria for categorization of isolates were including: strong biofilm producer $(4 \times \mathrm{ODc}<\mathrm{OD})$, moderate biofilm producer $(2 \times \mathrm{ODc}<\mathrm{OD}<4 \times \mathrm{ODc})$, weak biofilm producer (ODc $<\mathrm{OD}<2 \times \mathrm{ODc}$ ) and no biofilm producer $(\mathrm{OD}<\mathrm{ODc})[23,24]$.

\section{Detection of resistance genes}

DNA was extracted using the DNA extraction kit (High Pure PCR Template Preparation Kit-Roche, Germany, Lot. No. 10362400) according to the manufacturer's instruction. Detection of resistance genes among all isolates, including ESBL-encoding genes $\left(b l a_{\mathrm{TEM}}, b l a_{\mathrm{SHV}}\right.$, $b l a_{\mathrm{CTX}-\mathrm{M}}, b l a_{\mathrm{GES}}, b l a_{\mathrm{PER}}$, and $\left.b l a_{\mathrm{VEB}}\right)$, carbapenemases genes $\left(b l a_{\mathrm{OXA}-48}, b l a_{\mathrm{NDM}}, b l a_{\mathrm{KPC}}, b l a_{\mathrm{VIM}}\right.$, and $\left.b l a_{\mathrm{IMP}}\right)$, and two fosfomycin resistance genes (fos $A$ and fos $C 2$ ), was performed by polymerase chain reaction (PCR) amplification using the specific primers [25-29] and confirmed by sequencing. $P$. aeruginosa containing $b l a_{G E S} b l a_{P E R}$ $b l a_{V E B}, b l a_{\mathrm{VIM}}, b l a_{\mathrm{IMP}}$ genes and $K \cdot$ pneumoniae containing other genes received from Shahid Beheshti University of Medical Sciences, Tehran, Iran, were used as positive controls. PCR products were purified using a PCR purification Kit (Bioneer Co., Korea) and then, nucleotide sequencing of amplicons was performed by an ABI PRISM 3700 sequencer (Macrogen Co., Korea). Nucleotide sequences were analyzed using Chromas software version 1.45 (http://www.technelysium.com.au) and NCBI BLAST program (https://blast.ncbi.nlm.nih.gov/ Blast.cgi).

\section{Molecular analysis of colistin resistance}

Analysis of plasmid-mediated colistin resistance was performed by PCR amplification of $m c r-1, m c r-2, m c r-3$, and $m c r-4$ among all colistin-resistant $K$. pneumoniae isolates. All colistin-resistant $K$. pneumoniae isolates were also examined for the presence of mutations in the chromosomally-encoded modifications of the LPS, including $m g r B$, pmrA, pmrB, phoP, and phoQ genes [30, 31]. Insertion sequences (ISs) were identified using the IS finder tool (https://www-is.biotoul.fr/index.php). Genomic DNA from two colistin-sensitive $K$. pneumoniae clinical isolates and K. pneumoniae ATCC 700603 were used as control.

\section{Real-time quantitative reverse transcription PCR}

Colistin-resistant isolates were assessed for expression of $p m r C, p m r A, p m r B, p m r D$, $p m r E$, and $p m r K$ genes using specific primers $[29,31,32]$. rpsL gene encoding a ribosomal protein was used as housekeeping gene to normalize the levels of transcripts tested. Total RNA was extracted 
from the cultures grown in the mid-log phase of growth in Luria-Bertani broth (Merck, Darmstadt, Germany) by the RNX-Plus Kit (Cat. No., RN7713C, Sinaclon, Iran) according to the manufacturer's instruction. The contaminating DNA was removed by RNase-free DNase I (Fermentas, Thermo Fisher Scientific Inc., USA). The total RNA concentration was determined by Nanodrop (WPA Biowave II Nanospectrophotometer, USA). DNasetreated RNA was reverse-transcribed into cDNA using the Takara Kit (Japan). RNA samples were checked for contaminating DNA by PCR. Real-time PCR assay was performed on synthesized cDNA using the Power SYBR Green PCR Master Mix (Bioneer, Korea) on a Corbett Rotor-Gene 6000 real-time rotary analyzer (Corbett Life Science, Australia). Each amplification protocol included a first denaturation step of $10 \mathrm{~min}$ at $94{ }^{\circ} \mathrm{C}$, followed by 40 cycles of $20 \mathrm{~s}$ at $94{ }^{\circ} \mathrm{C}$ and $45 \mathrm{~s}$ at $59^{\circ} \mathrm{C}$. All samples were run in triplicate. Data were compared to those obtained with the rpsL gene. The expression level of transcripts was calculated based on $2^{-\Delta \Delta C T}$ method (relative) against that for the susceptible isolate, $K$. pneumoniae ATCC 700603. Experiments were repeated three times. The parameter $\mathrm{Ct}$ was defined as the threshold cycle number at which the first detectable fluorescence generated by the binding of SYBR Green I dye to the minor groove of double-stranded DNA began to increase exponentially.

\section{Plasmid manipulation and analysis}

NDM positive strains were selected for plasmid analysis. Plasmid DNA of isolates, transconjugants, and transformants was extracted by using the Roche kit (Cat. No. 11754777 001) according to the manufacturer's instructions. Electroporation was used to transform plasmids encoding $b l a_{\mathrm{NDM}}$ into $E$. coli TOP10. The $b l a_{\mathrm{NDM}}$ transformants were selected on $\mathrm{MH}$ agar (Merck-Germany) supplemented with meropenem $(0.5 \mathrm{mg} / \mathrm{L})$ (Sigma-Aldrich). Conjugation experiments were carried out in LB broth with sodium-azide-resistant E. coli J53AzR as the recipient. Cultures of donor and recipient cells in logarithmic phase were added to $4 \mathrm{~mL}$ of fresh $\mathrm{LB}$ broth and were then incubated at $37{ }^{\circ} \mathrm{C}$ overnight without shaking. The transconjugants were selected on $\mathrm{MH}$ agar (Merck-Germany) supplemented with meropenem $(0.5 \mathrm{mg} / \mathrm{L})$ or ceftazidime (1, 2 and $4 \mathrm{mg} / \mathrm{L})$ with sodium azide $(100 \mathrm{mg} / \mathrm{L})$ (Sigma-Aldrich).

\section{PCR-based replicon typing}

All transconjugants and transformants were typed by a PCR method based on replicons of the major plasmid incompatibility groups among Enterobacteriaceae [33].

\section{Multi-locus sequence type (MLST) analysis}

Genotyping by MLST analysis was conducted to characterize diversity and epidemiology of $b l a_{\mathrm{NDM}^{-}}$carrying K. pneumoniae isolates [34]. Briefly, PCR for seven housekeeping genes, including rpoB, gapA, mdh, phoE, $p g i, \inf B$, and $\operatorname{ton} B$ was carried out. Results were analyzed according to the Institute Pasteur Klebsiella MLST database (https://bigsdb.pasteur.fr/klebsiella/ klebsiella.html). Unique sequence (allele) number for each gene was assigned on the basis of the information in the K. pneumoniae MLST database to determine specific sequence types (ST). A combination of the allelic sequences of the seven genes yielded the allelic profile for each isolate.

\section{Repetitive extragenic palindromic (rep)-PCR typing}

Rep-PCR analyses were conducted with the single primer BoxA1R (5'-CTA CGG CAA GGC GAC GCT GAC G-3') [35]. To determine phylogenetic relationships, rep-PCR profiles were analyzed by GelCompar II software (Applied Maths, Belgium) using the Pearson's correlation coefficient with unweighted paired group method using arithmetic averages (UPGMA) as well as at the $80 \%$ similarity level [35].

\section{Statistical analysis}

Chi-squared test was performed using SPSS software, 21.0 (SPSS Inc., Chicago, IL, USA) to check for any significant differences between datasets. A significant level of $P \leq 0.05$ was considered statistically significant.

\section{Results \\ Bacterial isolates}

165 non-duplicate non-consecutive isolates of $E$. coli and $K$. pneumoniae were collected from 73 (45.5\%) females and $92(54.5 \%)$ males admitted at five Iranian hospitals during the September 2016 to August 2018. The age range of patients was between 1 and 87 years. The origins of isolates were 114 in urine, 39 in tracheal aspirates, 4 in wounds, and 8 in blood.

\section{Antimicrobial susceptibility}

Antibiotic resistance patterns of 165 isolates of $K$. pneumoniae and E. coli are shown in Table 1. The lowest rate of resistance was observed against tigecycline $(\mathrm{n}=9,5.5 \%)$, and fosfomycin $(\mathrm{n}=26,15.8 \%)$. The number of isolates with multidrug-resistant (MDR), extensively drug-resistant (XDR), and pandrug-resistant (PDR) phenotype was 32 (E. coli: 27, K. pneumoniae: 5), 120 (E. coli: 77, K. pneumoniae: 43), 1 (K. pneumoniae: $1)$, respectively. The MIC ranges, $\mathrm{MIC}_{50}, \mathrm{MIC}_{90}$, and the 


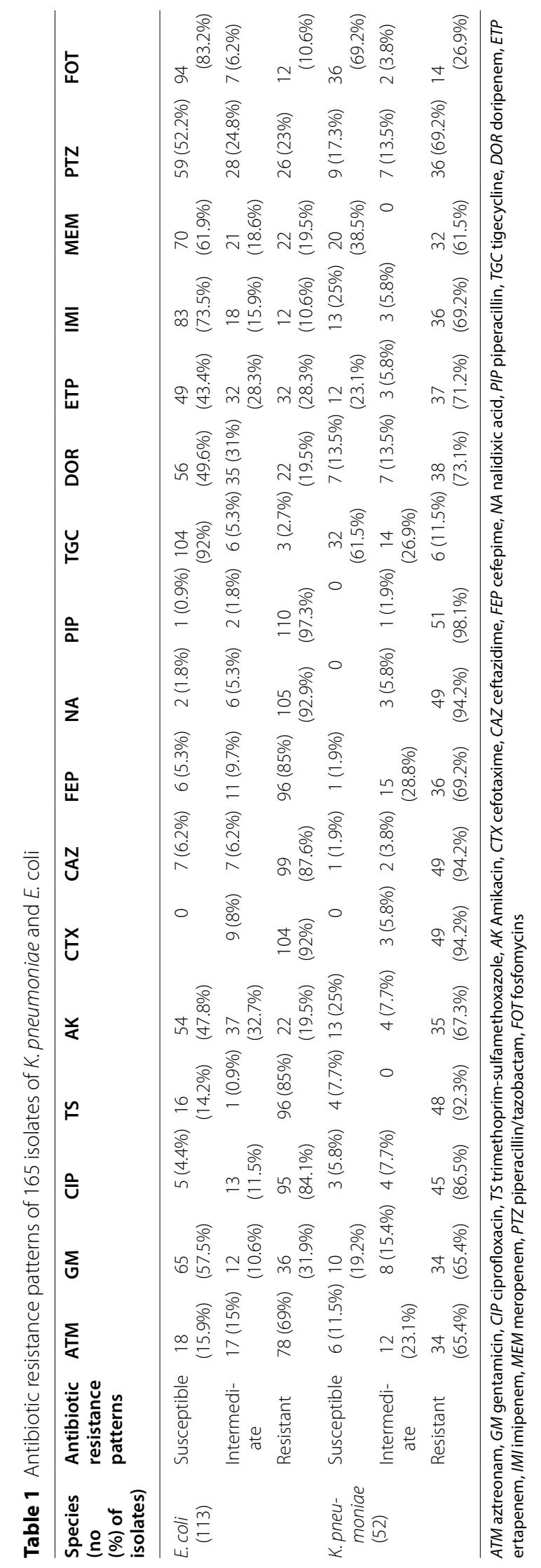


Table 2 MIC of the K. pneumoniae and E. coli clinical isolates $(n=165)$

\begin{tabular}{|c|c|c|c|c|c|c|}
\hline \multirow[t]{2}{*}{ Antibiotic } & \multicolumn{3}{|c|}{ MIC $(\mu \mathrm{g} / \mathrm{mL})$} & \multicolumn{3}{|l|}{ No (\%) } \\
\hline & Range & $50 \%$ & $90 \%$ & Resistant & intermediate & susceptible \\
\hline Ceftazidime & $2-\geq 512$ & 64 & 512 & 153 (92.7\%) & $4(2.42 \%)$ & $8(4.84 \%)$ \\
\hline Cefotaxime & $2-\geq 512$ & 64 & 512 & 153 (92.7\%) & $4(2.42 \%)$ & $8(4.84 \%)$ \\
\hline Cefepime & $2-512$ & 32 & 256 & 150 (90.9\%) & 0 & 15 (9.1\%) \\
\hline Ciprofloxacin & $2-512$ & 32 & 128 & 150 (90.9\%) & 0 & 15 (9.1\%) \\
\hline Imipenem & $\leq 2-128$ & 2 & 32 & 55 (33.3\%) & $10(6 \%)$ & $95(57.6 \%)$ \\
\hline Meropenem & $\leq 2-256$ & 2 & 32 & $55(33.3 \%)$ & $10(6 \%)$ & 95 (57.6\%) \\
\hline Colistin & $0.25-128$ & 0.5 & 4 & $16(9.7 \%)$ & 0 & 149 (90.3\%) \\
\hline
\end{tabular}

percentages of isolates resistant, intermediate, or susceptible isolates to the seven antimicrobial agents are shown in Table 2.

K54 was found to be non-susceptible to all antibiotics tested, which includes cephalosporins, penicillins, carbapenems, aztreonam, aminoglycosides, ciprofloxacin, colistin, tetracyclines, tigecycline, trimethoprim-sulfamethoxazole and fosfomycin (Table 3). Thus, the isolate can truly be described as pandrug-resistant.

\section{$\beta$-lactamase phenotype}

The prevalence of ESBL-producing E. coli and K. pneumoniae was $49.6 \%(\mathrm{n}=82)$ and $26.6 \%(\mathrm{n}=44)$, respectively. The proportion of ESBL-producing E.coli and $K$.

Table 3 MIC and molecular features related to NDM-producing and colistin-resistant K. pneumoniae isolates

\begin{tabular}{|c|c|c|c|c|c|c|c|c|c|c|}
\hline \multirow[t]{2}{*}{ Isolates } & \multicolumn{7}{|c|}{$\mathrm{MIC}(\mu \mathrm{g} / \mathrm{mL})$} & \multirow[t]{2}{*}{ ESBL genes } & \multirow[t]{2}{*}{ MBL genes } & \multirow[t]{2}{*}{ Sensitivity to antibiotic } \\
\hline & CIP & CTX & CEP & CAZ & IMI & MER & $\mathrm{CO}$ & & & \\
\hline K37 & 128 & 64 & 64 & 64 & 128 & 128 & 128 & CTX-M, TEM, SHV & - & FOS \\
\hline K38 & 128 & 64 & 64 & 64 & 128 & 128 & 64 & CTX-M, TEM & - & TGC, FOS \\
\hline K50 & 256 & 512 & 512 & 512 & 8 & 8 & 64 & CTX-M, TEM, SHV & - & TGC, FOS \\
\hline K52 & 256 & 512 & 512 & 512 & 8 & 16 & 4 & CTX-M & - & TGC \\
\hline K53 & 128 & 512 & 512 & 512 & 8 & 8 & 4 & CTX-M, SHV & - & TGC \\
\hline$K 54^{\mathrm{a}}$ & 256 & 128 & 128 & 128 & 32 & 16 & 16 & CTX-M, TEM & - & - \\
\hline K57 & 256 & 16 & 16 & 16 & 16 & 16 & 4 & CTX-M, SHV & - & TGC \\
\hline K83 & 128 & 32 & 32 & 32 & 32 & 8 & 128 & CTX-M, TEM, SHV & - & TGC, FOS \\
\hline K101 & 128 & 512 & 512 & 512 & 64 & 64 & 128 & CTX-M,TEM, SHV & - & TGC, FOS \\
\hline K111 & 16 & 128 & 128 & 128 & 8 & 16 & 4 & CTX-M, TEM & - & TGE, FOS \\
\hline K130 & 128 & 512 & 512 & 512 & 8 & 32 & 8 & CTX-M. TEM, SHV & - & TGC \\
\hline K134 & 16 & 64 & 64 & 64 & 8 & 8 & 4 & CTX-M, TEM & - & FOS, TGE \\
\hline K136 & 128 & 512 & 64 & 512 & 16 & 16 & 8 & TEM, SHV & - & MER \\
\hline K148 & 16 & 8 & 16 & 16 & 16 & 32 & 4 & TEM & - & TGE \\
\hline K151 & 16 & 16 & 16 & 16 & 4 & 4 & 4 & TEM & - & DOR,TGE \\
\hline K158 & 8 & 16 & 16 & 16 & 4 & 4 & 4 & TEM & - & DOR, TGE, FOS \\
\hline K36 & 128 & 32 & 32 & 32 & 128 & 128 & 1 & CTX-M, TEM, SHV & NDM-1 & $\mathrm{CO}$ \\
\hline K72 & 128 & 32 & 32 & 32 & 32 & 64 & 1 & CTX-M, TEM, SHV & NDM-1 & $\mathrm{CO}, \mathrm{TGC}, \mathrm{FOS}$ \\
\hline K120 & 128 & 512 & 512 & 512 & 16 & 16 & 1 & CTX-M, TEM, SHV & NDM-1 & $\mathrm{CO}$ \\
\hline K161 & 128 & 32 & 32 & 32 & 128 & 32 & 1 & CTX-M, TEM, SHV & NDM-6 & $\mathrm{CO}$ \\
\hline K162 & 64 & 64 & 64 & 64 & 64 & 64 & 1 & CTX-M, TEM, SHV & NDM-6 & $\mathrm{CO}$ \\
\hline K165 & 128 & 64 & 64 & 64 & 64 & 64 & 1 & CTX-M, TEM, SHV & NDM-6 & $\mathrm{CO}$ \\
\hline
\end{tabular}

CIP ciprofloxacin, CTX cefotaxime, CAZ ceftazidime, FEP cefepime, TGC tigecycline, DOR doripenem, ETP ertapenem, IMI imipenem, MEM meropenem, FOT fosfomycin/ trometamol, $\mathrm{CO}$ colistin

a Pandrug-resistant 
pneumoniae showing resistance to cephalosporin were significantly higher than non-ESBL-producing strains $(p<0.05)$.

\section{Metallo $\beta$-lactamase phenotype}

The prevalence of MBL-producing E. coli and K. pneumoniae were $1.8 \%(\mathrm{n}=2)$ and $38.5 \%(\mathrm{n}=20)$, respectively. All MBL-producing isolates were resistant to carbapenems and cephalosporins $(P \leq 0.05)$.

\section{Carbapenemase phenotype}

According to the results of the Carba NP test, only $22 \mathrm{~K}$. pneumoniae isolates produced carbapenemase enzymes. As with the MBL phenotypes, all carbapenemase-producing isolates were resistant to carbapenem and cephalosporin antibiotics $(p \leq 0.05)$.

\section{Biofilm phenotype}

Biofilm phenotype accounted for 159 out of 165 isolates (96.36\%): 33 isolates (20\%) produced strong biofilm, 31 isolates (18.8\%) produced moderate biofilm, and 95 isolates $(57.6 \%)$ produced weak biofilm; whereas 6 isolates (3.6\%) did not form biofilm. Among 82 ESBL-producing E. coli, $12(14.63 \%)$ isolates were strong biofilm-producers, $11(13.41 \%)$ were moderate biofilm-producers, 55 (67\%) were weak biofilm-producers, and 4 (4.88\%) isolates produced no biofilm. Moreover, among the 44 ESBL-producing $K$. pneumoniae, 16 (36.36\%) isolates were strong biofilm-producers, $12(27.27 \%)$ were moderate biofilm-producers, and $16(36.36 \%)$ isolates were identified as weak biofilm-producers.

\section{Antimicrobial resistance genes}

The prevalence of isolates carrying ESBL-encoding determinants was $78.2 \%(\mathrm{n}=129)$. The $b l a_{\mathrm{TEM}}, b l a_{\mathrm{SHV}}$, and $b l a_{\text {СТХ-M }}$ genes were detected in 98 (59.4\%), 54 (32.7\%), and 77 (46.7\%) isolates, respectively; while no isolates were positive for the $b l a_{\mathrm{GES}}, b l a_{\mathrm{PER}}$, and $b l a_{\mathrm{VEB}}$ genes (Table 4). In addition, the prevalence of MBL-producing E. coli and K. pneumoniae were $1.8 \%(\mathrm{n}=2)$ and $38.5 \%$ $(\mathrm{n}=20)$, respectively, of which $6(6.5 \%)$ K. pneumoniae isolates were positive for for $b l a_{\mathrm{NDM}}$ gene $\left(b l a_{\mathrm{NDM}-6}: 3\right.$, $b l a_{\mathrm{NDM}-1}:$ 3) (Table 4). No bla $_{\mathrm{IMP}}, b l a_{\mathrm{VIM}}, b l a_{\mathrm{SIM}}, b l a_{\mathrm{GIM}}$, $b l a_{\mathrm{SPM}}$, and $b l a_{\mathrm{KPC}}$ genes were detected. The $b l a_{\mathrm{OXA}-48 \text {-like }}$ gene was identified among 17 (10.30\%) of isolates. While no plasmid-mediated colistin resistance genes of $m c r-1$, $m c r-2, m c r-3, m c r-4$, and $m c r-4$ were detected in isolates, 16 (9.7\%) K. pneumoniae were identified as colistinresistant. Moreover, the primers targeting fos $A$ and fos $C 2$ genes did not provide any amplicon in fosfomycin-resistant isolates. The results from real-time PCR analysis were consistent with PCR and sequencing.

\section{Molecular analysis of colistin resistance}

The $m c r-1, m c r-2, m c r-3$, and $m c r-4$ genes were not found in any of the colistin-resistant isolates, we focused on other mechanisms of resistance, specifically $m g r B$ gene inactivation and the presence of the mutations in the $p m r A, p m r B$, $p h o P$, and $p h o Q$ genes. Sequence analysis of the $m g r B$ gene showed that one isolate (K37) generated amplicon that was larger than those produced by $K$. pneumoniae $\mathrm{K} 85$ control isolate and colistin-susceptible K. pneumoniae ATCC 700603 strain. Amplicon sequencing revealed that insertional inactivation had occurred in the coding region of the $K$. pneumoniae K37 mgrB gene. Also, occurred at nucleotide 75 and was raised

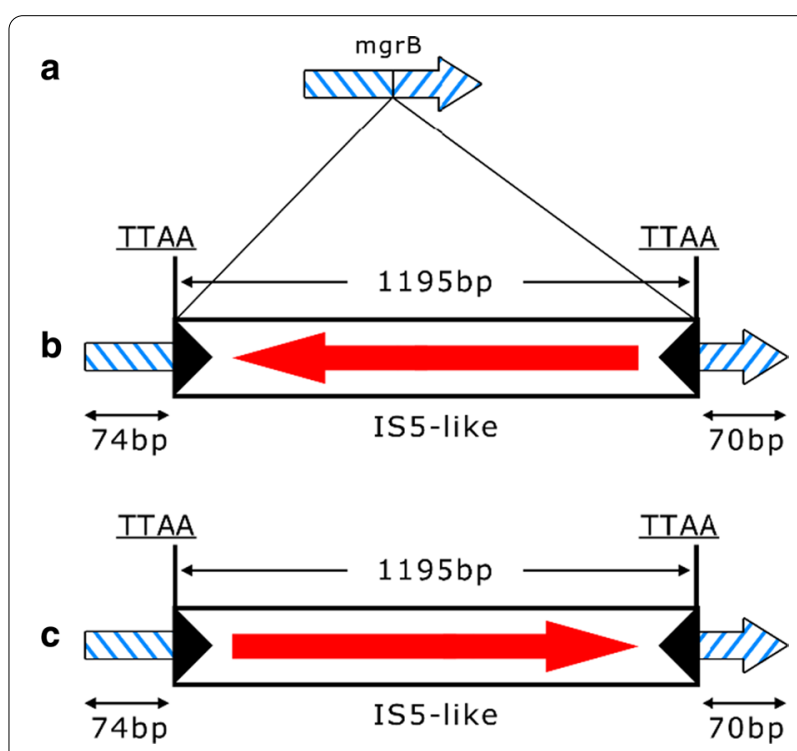

Fig. 1 Schematic representation of the different insertion events identified in the $m g r B$ gene. a The intact $m g r B$ gene as found in wild type isolates and isolate (b) $\mathrm{mgrB}$ truncated by IS5-like in $\mathrm{k37}$ isolate. $\mathbf{C}$ mgrB truncated by IS5-like as identified by Laurent Poirel et al.[65]

Table 4 Prevalence of beta-lactamase genes among isolates

\begin{tabular}{|c|c|c|c|c|c|c|c|c|}
\hline No (\%) of isolates & $b l a_{\mathrm{TEM}}$ & $b l a_{\mathrm{SHV}}$ & $b l a_{\text {СТXM }}$ & $b l a_{\mathrm{TEM}}, b l a_{\mathrm{SHV}}$ & $b / a_{\mathrm{TEM}}, b l a_{\mathrm{CTXM}}$ & $b l a_{\mathrm{SHV}}, b l a_{\mathrm{CTXM}}$ & $b l a_{\mathrm{TEM}}, b l a_{\mathrm{SHV}}, b l a_{\mathrm{CTXM}}$ & $\begin{array}{l}b / a_{\mathrm{TEM}}, b l a_{\mathrm{SHV}} \\
b l a_{\mathrm{CTXM}} \\
b / a_{\mathrm{NDM}}\end{array}$ \\
\hline E. coli (n: 113) & $19(16.8 \%)$ & $3(2.6 \%)$ & $16(14.1 \%)$ & $8(7.1 \%)$ & $19(16.8 \%)$ & $3(2.6 \%)$ & $12(10.6 \%)$ & 0 \\
\hline K. pneumoniae (n: 52) & $13(25 \%)$ & $5(9.6 \%)$ & $1(1.9 \%)$ & $4(7.7 \%)$ & $7(13.5)$ & $3(5.8 \%)$ & $10(19.2 \%)$ & $6(11.5 \%)$ \\
\hline
\end{tabular}


by insertional sequence that shared $99 \%$ identity at the nucleotide level with IS5 family of insertion sequences (Fig. 1). Insertional inactivation was not detected in other isolates tested. However, K83, K101, K50, and K130 isolates had premature amber stop codon (TAG) due to a C-to- $\mathrm{T}$ change at position 88 and $\mathrm{K} 136$ had premature opal stop codon (TGA) due to a C-to-A change at position 117, resulting in a truncated $\mathrm{MgrB}$ protein containing 29 and 39 amino acids, respectively. Amino acid substitutions were detected in PmrB, PhoP and PhoQ proteins. Nucleotide $A$ at the position 469 of the $p m r B$ gene was converted to $\mathrm{C}$ in $\mathrm{K} 101$ isolate, leading to Thr157Pro substitution. At nucleotide position of 171, the phoP gene underwent $\mathrm{A}$ to $\mathrm{C}$ conversion, resulting in single substitution Glu57Asp in the isolate K37. The isolate K83 showed nucleotide conversion A to $\mathrm{G}$ at the position 449 of phoQ gene, leading to substitution Asp150Gly. No amino acid substitutions were detected in PmrA protein.

\section{Overexpression of pmrCAB, pmrHFIJKLM, and phoPQ operons}

Expression level of pmr and pho genes was measured to evaluate the effect of mutations on colistin-resistant isolates. Results revealed increased expression level of 1.2-8.6 fold for $p m r A, 1.57-5.09$ fold for $p m r B, 0.93-8.8$ fold for $p m r C, 2.17-17$ fold for $p m r K, 2.35-15.02$ fold for phoP, and 2.13-9.28 fold for phoQ genes; whereas no differences in expression levels were observed for $p m r D$ and pmrE genes (Fig. 2a). Analysis of mRNA transcript in K37 isolate with an inactivated $m g r B$ gene revealed a significant increase in expression level of genes $p m r A$ (8.6-fold), pmrB (5.2-fold), pmrC (7.3-fold), pmrK (17.1-fold), phoP (14.5-fold), and phoQ (9.3-fold). No insertional inactivation of $m g r B$ gene was found in K83 and K101 isolates. Also, features of the colistin-resistant isolates has been showed in Table 5. Relative expression levels of genes in PDR strain shown in Fig. $2 \mathrm{~b}$.

\section{Transformation and conjugation assays}

Plasmids carrying $b l a_{\mathrm{NDM}-1}$ and $b l a_{\mathrm{NDM}-6}$ genes in all six strains were successfully transferred to $E$. coli TOPO10 and $E$. coli $\mathrm{J} 53$ recipient strains. The antimicrobial resistance profile of the transformants and transconjugants are shown in Table 6. PCR confirmed the presence of the $b l a_{\mathrm{NDM}-1}$ and $b l a_{\mathrm{NDM}-6}$ genes in the transformants and transconjugants; all these isolates harbored also bla ${ }_{\mathrm{CTX}-\mathrm{M}}$, $b l a_{\mathrm{TEM}}$ and $b l a_{\mathrm{SHV}}$ genes (Table 6).

\section{Plasmid replicon typing}

Plasmid replicon typing revealed that $3 b l a_{\mathrm{NDM}-1}$-carrying- and 3 bla $a_{\mathrm{NDM}-6}$-carrying $K$. pneumoniae isolates contained plasmid types belonging to IncF and IncL/M, respectively (Table 6).

\section{MLST analysis results}

STs were identified among the $6 b l a_{\mathrm{NDM}^{-}}$-arrying $K$. pneumoniae isolates, including ST147 $(\mathrm{n}=4)$, ST15 $(n=1)$, and ST3299 $(n=1)$. Among the isolates that belonged to ST147, 3 isolates were originated from urine specimens (Table 6).

\section{Rep-PCR analysis}

To evaluate the genetic diversity, $6 b l a_{\mathrm{NDM}^{-}}$-positive and 16 colistin-resistant isolates were subjected to rep-PCR fingerprinting. Isolates were divided into 3 common types (CT) containing 2-4 isolates and 12 single types (ST). Among these, a dominant clone was from Tehran and originated from urine samples. The genotypic pattern of the dominant clone revealed that all isolates harbored ESBL genes.

\section{Discussion}

The excessive and inappropriate use of antibiotics against microbial infections in Iran has led to increased rate of drug resistance in recent decades [36]. Today, clinicians rely increasingly on carbapenems (i.e., imipenem, meropenem, doripenem, etc.) to treat infections due to multidrug-resistant bacteria. CRE strains have been reported in several hospital outbreaks and have the propensity to spread rapidly at local, regional and international levels. The continual emergence of CREs is a major threat to public health worldwide [1]. The worsening condition is that CRE strains show resistance progressively toward a wide range of antimicrobial classes [36, 37] [38]. In this study, about $73.1 \%$ of K. pneumoniae and $28.3 \%$ of E. coli isolates were resistant to at least one of the carbapenems tested. Among the included isolates, the highest rates of resistance belonged to piperacillin $(n=161,97.6 \%)$, nalidixic acid ( $\mathrm{n}=154,93.3 \%)$, and cefotaxime $(\mathrm{n}=153$, 92.7\%). On the other hand, the lowest resistance rate was observed for tigecycline $(n=9,5.5 \%)$ followed by colistin $(n=16,9.7 \%)$, and fosfomycin $(n=26,15.8 \%)$, indicating that these antibiotics have increasingly become primary options for treatment of multi-resistant strains of $K$. pneumoniae and E. coli. Our results indicated that the resistance rate of $K$. pneumoniae isolates against colistin was $30.77 \%$ with the range MIC $4-128 \mu \mathrm{g} / \mathrm{mL}$. Colistin remains the last line of defense against many Gram-negative bacilli. However, colistin-resistant and even pandrug-resistant Gram-negative bacilli have already been reported [39]. According to reports from other studies around the world, the rate of colistin resistance among carbapenem-resistant $K$. pneumoniae has progressively 


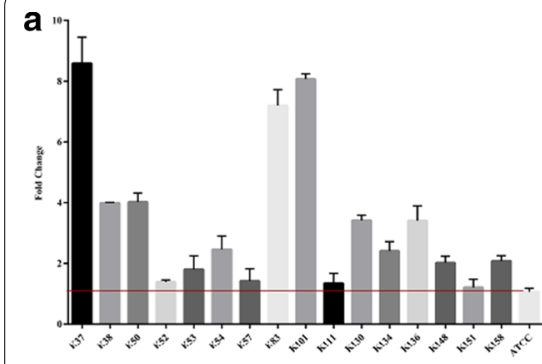

pures

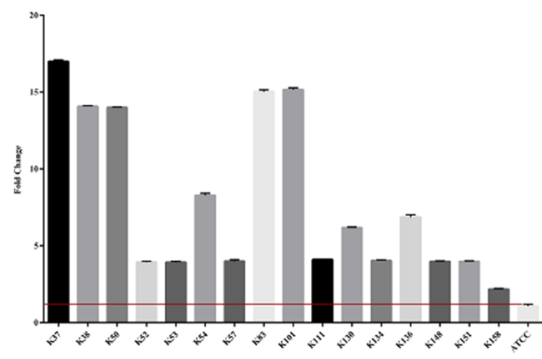

pmink

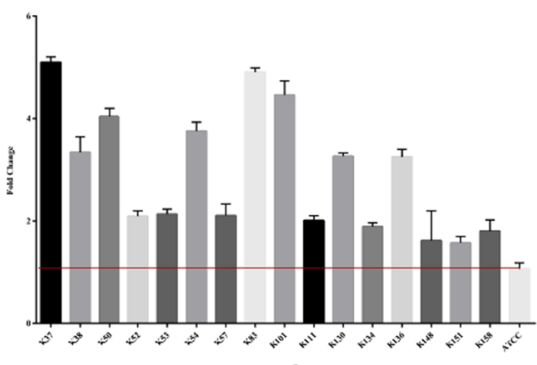

pmrk

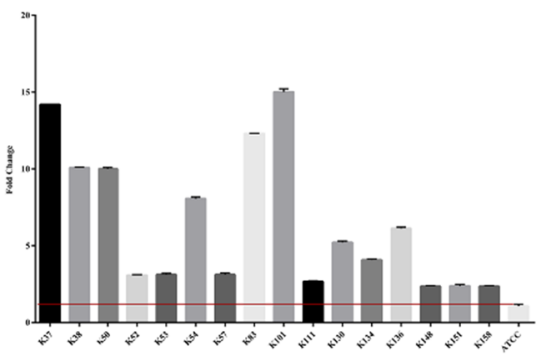

phop

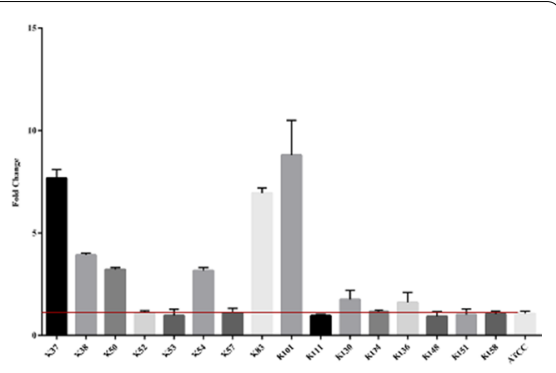

pmerc

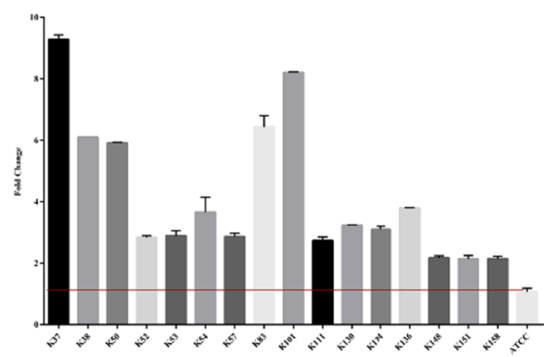

phoo

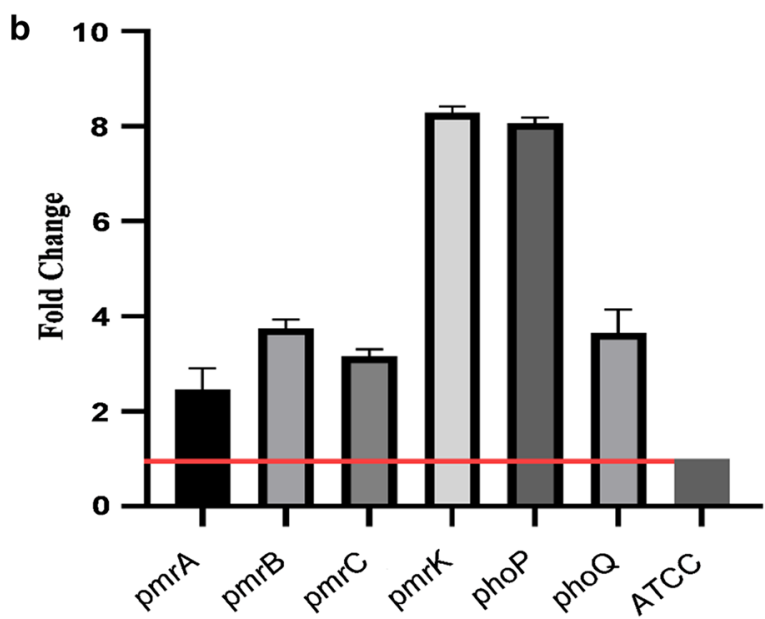

PDR strain(k54)

Fig. 2 a Relative expression levels of the $p m r A, p m r B, p m r C, p m r E, p m r D, p m r K$, phoP and phoQ genes in colistin-resistant $K$. pneumoniae isolates. No differences in expression levels were observed for pmrD and pmrE genes. ATCC: K. pneumoniae ATCC 700603. b Relative expression levels of the pmrA, pmrB, pmrC, pmrK, phoP and phoQ genes in PDR strain (K54). ATCC: K. pneumoniae ATCC 700603

increased from $<2 \%$ to $9 \%$. In the last decade in Europe, resistance to colistin has increased to one third of carbapenem-resistant isolates. In addition, multiple outbreaks of colistin-resistant K. pneumoniae have been reported in different regions of the world [40, 41].

In this study, the prevalence of ESBL-producing E. coli and $K$. pneumoniae were $49.6 \%$ and $26.6 \%$, respectively. To date, the ESBL and MBL enzymes has been identified in almost all of the world, including many countries in Asia, Africa, Americas, the Europe, and Australia $[42,43]$. The high rate of ESBL and MBL prevalence in the world and its widespread dissemination is a cause of concern. The $b l a_{\mathrm{NDM}}$ are plasmid-mediated genes responsible for resistance to carbapenems and are often co-harbored with different resistance determinants, such as those encoding ESBL. In this study, 98 (59.4\%), 54 (32.7\%), 77 (46.7\%), 3(1.8\%) and 3(1.8\%) isolates harbored $b l a_{\mathrm{TEM}}, b l a_{\mathrm{SHV}}, b l a_{\mathrm{CTX}-\mathrm{M}}, b l a_{\mathrm{NDM}-1}$ and $b l a_{\mathrm{NDM}-6}$ $\beta$-lactamase genes, respectively. All three $K$. pneumoniae isolates carrying $b l a_{\mathrm{NDM}-6}$ and one isolate harboring $b l a_{\mathrm{NDM}-1}$ belonged to the ST147 clone. While each of the two remaining isolates that were positive for $b l a_{\mathrm{NDM}-1}$ 


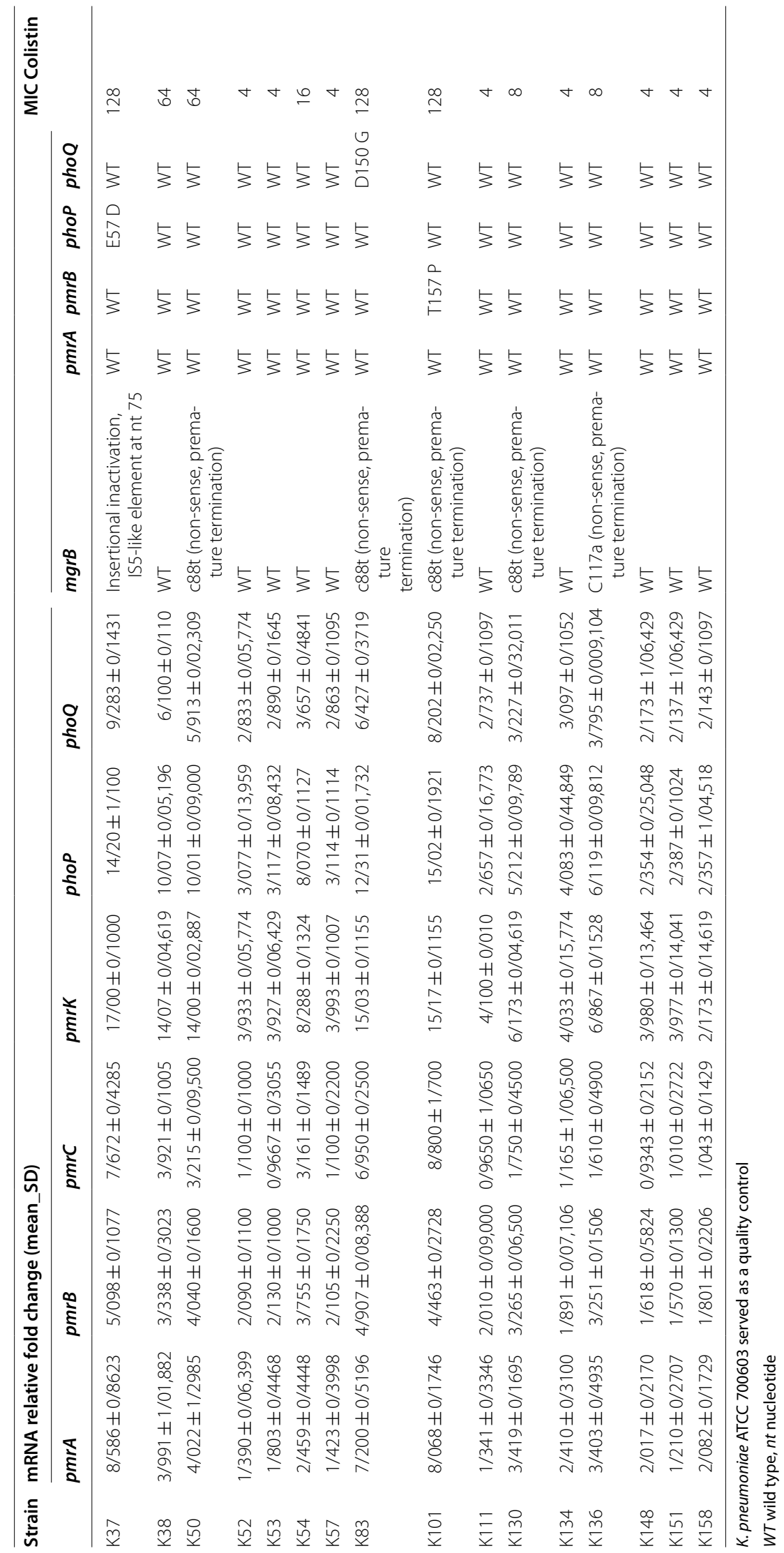


Table 6 The features related to NDM-producing K. pneumoniae isolates in Iran

\begin{tabular}{|c|c|c|c|c|c|c|c|c|c|c|c|c|}
\hline \multirow{2}{*}{$\begin{array}{l}\text { Number of } \\
\text { isolate }\end{array}$} & \multirow[t]{2}{*}{ Specimen } & \multirow[t]{2}{*}{ Ward } & \multicolumn{7}{|c|}{$\mathrm{MIC}(\mu \mathrm{g} / \mathrm{mL})$} & \multirow[t]{2}{*}{ ST } & \multirow[t]{2}{*}{ Other genes } & \multirow[t]{2}{*}{ Plasmid type } \\
\hline & & & CIP & CTX & CEP & CAZ & IMI & MEM & $\mathrm{CO}$ & & & \\
\hline K161 & Urine & Dialysis & 128 & 32 & 32 & 32 & 128 & 32 & 1 & 147 & CTX-M, TEM, SHV & IncL/M \\
\hline K162 & Urine & Dialysis & 64 & 64 & 64 & 64 & 64 & 64 & 1 & 147 & CTX-M, TEM, SHV & IncL/M \\
\hline K165 & Urine & Dialysis & 128 & 64 & 64 & 64 & 64 & 64 & 1 & 147 & CTX-M, TEM, SHV & $\operatorname{lncL} / \mathrm{M}$ \\
\hline K36 & Sputum & ICU & 128 & 32 & 32 & 32 & 128 & 128 & 1 & 147 & CTX-M, TEM, SHV & $\operatorname{lncF}$ \\
\hline K72 & Throat secretions & ICU & 128 & 32 & 32 & 32 & 32 & 64 & 1 & 15 & CTX-M, TEM, SHV & IncF \\
\hline K120 & Tracheal tube & $\mathrm{ICU}$ & 128 & 512 & 512 & 512 & 16 & 16 & 1 & 3299 & CTX-M, TEM, SHV & IncF \\
\hline
\end{tabular}

belonged separately to the ST15 and ST3299 clone. The

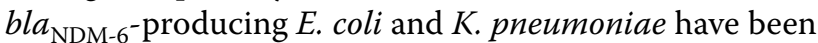
reported in New Zealand (ST101) [26] and India [44]. Distribution of $b l a_{\mathrm{NDM}-1}$ is greater than that of $b l a_{\mathrm{NDM}-6}$ and was reported from most regions of the world [45, 46].

Plasmids are elements that spread easily. This is one of the most difficult challenges to counteract the dissemination of antibiotic resistance genes and nosocomial infections. Analysis of transformants and transconjugants in the current study revealed that the $b l a_{\mathrm{NDM}-6}$ gene along with $b l a_{\mathrm{CTX}-\mathrm{M}-15}, b l a_{\mathrm{SHV}}$, and $b l a_{\mathrm{TEM}}$ were carried on transferable plasmids belonging to the IncL/M, while $b l a_{\mathrm{NDM}-1}$ gene was carried on transferable plasmids belonging to the IncF along with $b l a_{\mathrm{CTX}-\mathrm{M}-15}, b l a_{\mathrm{SHV}}$, and $b l a_{\mathrm{TEM}}$. Previous studies have reported that the spread of $b l a_{\mathrm{NDM}-1}$ is linked to different types of IncA/C, IncF, IncN, and untypeable plasmids [47]. Transferable IncL/M and IncF plasmids have greatly contributed to the dissemination of antibiotic resistance genes, such as $b l a_{\mathrm{NDM}-6}, b l a_{\mathrm{NDM}-1}, b l a_{\mathrm{TEM}}, b l a_{\mathrm{SHV}}$ as well as $b l a_{\mathrm{CTX}}$ M-15 among enterobacterial species [20, 48]. Other study reported that IncL/M and IncF plasmids have the ability to transfer to the susceptible strain, contributing to dissemination of antibiotic resistance genes, such as $b l a_{\mathrm{NDM}-1}$ and $b l a_{\mathrm{CTX}-\mathrm{M}-15}$ among $K$. pneumoniae [48, 49]. The three $K$. pneumoniae isolates carrying $b l a_{\mathrm{NDM}-6}$ belonged to ST147, suggesting the possibility of nosocomial infection. ST147 is among the major successful $K$. pneumoniae clone and, usually, is linked to IncF plasmids with $b l a_{\mathrm{KPC}}[50]$.

Colistin is a last-resort antibiotic that has been reintroduced today in clinical practices to treat infections caused by MDR CREs [13]. Acquired resistance to colistin is mostly caused by chromosomal mutations. However, a new plasmid-mediated colistin resistance gene, $m c r-1$, encoding a phosphoethanolamine transferase, has recently been described in China [51]. In our study, plasmid encoded $m c r-1, m c r-2, m c r-3$, and $m c r-4$ genes were not detected in any of the isolates. This results are in line with observations from other studies [29, 52]. Despite low prevalence, various variants of this gene have been reported from different regions of the world, including Iran [53-57]. In addition, many studies have shown the role of chromosomally-mediated mechanisms in colistin resistance [58]. MgrB, a small transmembrane protein with 47 amino acids that regulates the pmrHFIJKLM operon through a signaling cascade of PhoPQ, PmrD, and PmrAB and mediates potent negative feedback on the $\mathrm{PhoQ} / \mathrm{PhoP}$ regulatory system [59]. The insertional inactivation of $m g r B$ has been shown to be associated with overexpression of the phoPQ and pmrHFIJKLM operons, leading to modification of the LPS target, and eventually occurrence of colistin resistance [60]. The insertional inactivation of $m g r B$ gene due to IS5-like mobile element was observed in one isolate. In particular, the insertion of IS5-like mobile element at nucleotide 75 of $m g r B$ gene was in the same position to that found in other study [30, 52]. Similarly, a truncated MgrB protein by non-sense mutations $\mathrm{C} 88 \mathrm{~T}$ and $\mathrm{C} 117 \mathrm{~A}$ was identified in five isolates of the current study, causing premature termination [29, 52]. Remarkably, nine isolates had a wild type $m g r B$ gene and also showed no mutations in the other genes associated with resistance to colistin, suggesting the presence of unknown mechanism(s) for colistin resistance. In addition, the mutated $\mathrm{PmrB}$ protein, encoded by the $p m r B$ gene, is a part of the $p m r C A B$ operon, leading to lipopolysaccharide modification and resistance to colistin [31]. In the present study, the A469C mutation in $p m r B$ gene led to amino acid substitution Thr157Pro. Jayol et al., identified a Thr residue at position 157, therefore reinforcing the hypothesis that Thr157Pro might play a key role in acquired resistance to colistin [31].

In this study, single-base pair substitutions, including A449G leading to substitution Asp150Gly and A171C leading to substitution Glu57Asp were identified within the phoQ and phoP sequences, respectively. In other studies, amino acid substitutions in the $P h o Q$ gene have been associated with the colistin resistance phenotype Leu26Pro [61], Leu384Gln [62], Asp150Gly [63], Leu96Pro, and Leu348Gln [60]. In K. pneumoniae, amino 
acid substitutions, including Ser85Arg, Thr140Pro, Thr157Pro, Ser205Pro [60] and Thr 157Pro [31] in $p m r B$ [62], Leu26Gln and Arg114Ala in phoP [60, 63] have been previously reported. In our study, as in Mateur et al., no mutation in the pmrA gene was observed [63].

Colistin resistance has been found to be associated with upregulation of $p m r C A B$ and pmrHFIJKLM operons and $p m r E$ gene, resulting in lipidA modification in LPS structure. In this study, the relative expression of $p m r A$, $p m r B, p m r C, p m r K, p h o P$, and $p h o Q$ genes in isolates with $m g r B$ mutation (caused by IS element or nonsense mutation) was significantly higher than that of the $m g r B$ in wild type isolate and non-mutant colR isolates. In particular, overexpression of studied genes was observed in the $m g r B$-inactivated isolate compared to other isolates. Based on the results of this study and others, increased expression of the genes in $m g r B$-degraded isolates was more noticeable [29-31, 64]. Mutations in $p m r A / p m r B$ genes resulted in upregulation of the pmrABC and $p m r F-$ HIJKLM operons and $p m r E$ gene [31]. The current study revealed an overexpression of the $p m r A, p m r B, p m r C$, $p m r K$, phoP, and $p h o Q$ genes in the $p m r B$-mutated isolate compared to that of the $p m r B$ gene in wild-type colR $K$. pneumoniae, confirming that the $p m r B$ substitution could be responsible for increased expression levels of relevant genes. In the study of Jayol et al., the expression of $p m r A, p m r B, p m r C$, and $p m r K$ genes in isolates with $p m r B$-mutation were significantly increased in comparison with the that of $p m r B$ in wild type isolate [31]. Cheng et al., also found Arg256Gly replacement in the $p m r B$ in 8 of $26 \mathrm{col}-\mathrm{R}$ isolates. All of these eight isolates had overexpressed pmrHFIJKLM operon [61].

\section{Conclusion}

The prevalence of carbapenem and colistin resistance isolates among the patients with life-threatening infections hospitalized in critical wards is alarming. Unnecessary prescribing of antimicrobial drugs in patients is associated with the eradication of normal flora, leading to spread of MDR and XDR isolates. The emergence and spread of $b l a_{\mathrm{NDM}}$ and other antibiotic resistance genes in $K$. pneumoniae and E. coli will further limit the treatment options and threaten the public health of world.

This study demonstrated that carbapenem and colistin resistance $K$. pneumoniae strains are an emerging threat in different units and should be managed by implementation of timely identification and strict isolation methods that will help to reduce their severe outcomes and mortality rate in critically-ill patients. This study revealed the rapid emergence of extensively-drug resistant K. pneumoniae and E. coli isolates in patients. In addition, we report for the first time a pan-drug resistant strain from
Iran that could be a serious warning for the emergence of highly dangerous strains of nosocomial infections in the future.

The molecular mechanisms investigated in this study found to play a major role in development of resistance to antimicrobials, including carbapenem and colistin. Additional factors, such as increased amount of capsular polysaccharide, efflux pumps, and porins are mechanisms that still needs to be investigated.

\section{Abbreviations \\ CLSI: Clinical and Laboratory Standards Institute; TSB: Tryptic soy broth; OD: Optical density; PCR: Polymerase chain reaction; RT-qPCR: Quantitative reverse transcription-PCR; MLST: Multi-locus sequencing typing; UTIs: Urinary tract infections; MDR: Multidrug-resistant; CRE: Carbapenem-resistant Entero- bacteriaceae; MBL: Metallo- $\beta$-Lactamase; rep PCR: Repetitive extragenic palindromic.}

\section{Acknowledgements}

The present study was financially supported by the research Department of the School of Medicine, Shahid Beheshti University of Medical Sciences (Grant No.: 12606).

\section{Authors' contributions}

$J Y, A R, S D$ and AH conceived, designed and performed the experiments and analyzed the data. JY, AR, SD and AH wrote the paper. All authors read and approved the final manuscript.

\section{Funding}

This study was financially supported by the Research Department of the School of Medicine, Shahid Beheshti University of Medical Sciences (Grant No. 12606).

\section{Availability of data and materials}

The datasets generated and analyzed during this reasearch were included in the main document of this manuscript.

\section{Declarations}

Ethics approval and consent to participate

The clinical samples collected were in line with the patients' diagnostic stages and no additional samples were taken. This research was approved by the Ethics Committee of Shahid Beheshti University of Medical Sciences with the ethical code number IR.SBMU.MSP.REC.1397.629.

\section{Consent for publication}

Not applicable.

\section{Competing interests}

There are no conflicts of interest.

\section{Author details}

${ }^{1}$ Department of Microbiology, School of Medicine, Shahid Beheshti University of Medical Sciences, Tehran, Iran. ${ }^{2}$ Infectious Disease Research Center, Golestan University of Medical Sciences, Gorgan, Iran. ${ }^{3}$ Department of Microbiology, Faculty of Medicine, Golestan University of Medical Sciences, Gorgan, Iran.

Received: 30 November 2020 Accepted: 20 April 2021

Published online: 27 April 2021 


\section{References}

1. David S, Reuter S, Harris SR, Glasner C, Feltwell T, Argimon S, et al. Epidemic of carbapenem-resistant Klebsiella pneumoniae in Europe is driven by nosocomial spread. Nat Microbiol. 2019;4(11):1919-29.

2. Monegro AF, Regunath H. Hospital acquired infections. StatPearls: StatPearls Publishing; 2018.

3. Sharahi JY, Maleki DT, Rad ZR, Rad ZR, Goudarzi M, Shariati A, et al. In vitro antibacterial activity of curcumin-meropenem combination against extensively drug-resistant (XDR) bacteria isolated from burn wound infections. 2019.

4. Tavakolian S, Goudarzi H, Faghihloo E. LPS Induces microRNAs-9,-192, and-205 overexpression in colorectal cell lines SW480, HCT116. Middle East J Cancer. 2020;11(1):72-9.

5. Nordmann P, Poirel L, Walsh TR, Livermore DM. The emerging NDM carbapenemases. Trends Microbiol. 2011;19(12):588-95.

6. Abbasi E, Goudarzi H, Hashemi A, Chirani AS, Ardebili A, Goudarzi M, et al. Decreased carO gene expression and OXA-type carbapenemases among extensively drug-resistant Acinetobacter baumannii strains isolated from burn patients in Tehran, Iran. Acta Microbiol Immunol Hungarica. 2020.

7. Nasiri MJ, Mirsaeidi M, Mousavi SMJ, Arshadi M, Fardsanei F, Deihim $B$, et al. Prevalence and mechanisms of carbapenem resistance in Klebsiella pneumoniae and Escherichia coli: a systematic review and meta-analysis of cross-sectional studies from Iran. Microb Drug Resist. 2020;26(12):1491-502

8. Bengtsson-Palme J, Larsson DJ. Antibiotic resistance genes in the environment: prioritizing risks. Nat Rev Microbiol. 2015;13(6):396.

9. Rahmati Roodsari M, Fallah F, Taherpour A, Hakemi Vala M, Hashemi A Carbapenem-resistant bacteria and laboratory detection methods. Arch Pediatric Infect Dis. 2014;2(1):188-91

10. Dortet L, Poirel L, Nordmann P. Worldwide dissemination of the NDMtype carbapenemases in Gram-negative bacteria. BioMed Res Intern. 2014;2014.

11. Yoon E-J, Kang DY, Yang JW, Kim D, Lee H, Lee KJ, et al. New Delhi metallo-beta-lactamase-producing Enterobacteriaceae in South Korea between 2010 and 2015. Front Microbiol. 2018;9:571.

12. Huang $L$, Hu YY, Zhang R. Prevalence of fosfomycin resistance and plasmid-mediated fosfomycin-modifying enzymes among carbapenemresistant Enterobacteriaceae in Zhejiang, China. J Med Microbiol. 2017;66(9):1332-4.

13. Higashino HR, Marchi AP, Martins RCR, Batista MV, Neto LVP, de Castro Lima VAC, et al. Colistin-resistant Klebsiella pneumoniae co-harboring KPC and MCR-1 in a hematopoietic stem cell transplantation unit. Bone Marrow Transplant. 2019;54(7):1118-20.

14. Nation RL, Li J. Colistin in the 21st century. Curr Opin Infect Dis. 2009;22(6):535.

15. Kim S, Woo JH, Kim N, Kim MH, Kim SY, Son JH, et al. Characterization of chromosome-mediated colistin resistance in Escherichia coli isolates from livestock in Korea. Infect Drug Resist. 2019;12:3291

16. Du H, Chen L, Tang Y-W, Kreiswirth BN. Emergence of the mcr-1 colistin resistance gene in carbapenem-resistant Enterobacteriaceae. Lancet Infect Dis. 2016;16(3):287-8.

17. Pajand O, Darabi N, Arab M, Ghorbani R, Bameri Z, Ebrahimi A, et al. The emergence of the hypervirulent Klebsiella pneumoniae (hvKp) strains among circulating clonal complex 147 (CC147) harbouring bla NDM/ OXA-48 carbapenemases in a tertiary care center of Iran. Ann Clin Microbiol Antimicrob. 2020;19:1-9.

18. Weinstein MP. Performance standards for antimicrobial susceptibility testing. Clinical and Laboratory Standards Institute; 2019

19. Veeraraghavan B, Poojary A, Shankar C, Bari AK, Kukreja S, Thukkaram $B$, et al. In-vitro activity of tigecycline and comparator agents against common pathogens: Indian experience. J Infect Dev Countries. 2019:13(03):245-50.

20. Ahmad N, Ali SM, Khan AU. Molecular characterization of novel sequence type of carbapenem-resistant New Delhi metallo- $\beta$-lactamase-1producing Klebsiella pneumoniae in the neonatal intensive care unit of an Indian hospital. Int J Antimicrob Agents. 2019:53(4):525-9.

21. Gupta V, Soni R, Jain N, Chander J. In vitro cost-effective methods to detect carbapenemases in Enterobacteriaceae. J Lab Phys. 2018;10(1):101.

22. Nordmann P, Poirel L, Dortet L. Rapid detection of carbapenemaseproducing Enterobacteriaceae. Emerg Infect Dis. 2012;18(9):1503.
23. Pompilio A, Pomponio S, Crocetta V, Gherardi G, Verginelli F, Fiscarelli E, et al. Phenotypic and genotypic characterization of Stenotrophomonas maltophilia isolates from patients with cystic fibrosis: genome diversity, biofilm formation, and virulence. BMC Microbiol. 2011;11(1):159.

24. Stepanović S, Vuković D, Hola V, Bonaventura GD, Djukić S, Ćirković I, et al. Quantification of biofilm in microtiter plates: overview of testing conditions and practical recommendations for assessment of biofilm production by staphylococci. APMIS. 2007;115(8):891-9.

25. Heffernan HM, Woodhouse RE, Pope CE, Blackmore TK. Prevalence and types of extended-spectrum $\beta$-lactamases among urinary Escherichia coli and Klebsiella spp. in New Zealand. Int J Antimicrob Agents. 2009;34(6):544-9.

26. Williamson DA, Sidjabat HE, Freeman JT, Roberts SA, Silvey A, Woodhouse $\mathrm{R}$, et al. Identification and molecular characterisation of New Delhi metallo- $\beta$-lactamase-1 (NDM-1)-and NDM-6-producing Enterobacteriaceae from New Zealand hospitals. Int J Antimicrob Agents. 2012;39(6):529-33.

27. Ma Y, Xu X, Guo Q, Wang P, Wang W, Wang M. Characterization of fosA5, a new plasmid-mediated fosfomycin resistance gene in Escherichia coli. Lett Appl Microbiol. 2015;60(3):259-64

28. Liu Y-Y, Wang Y, Walsh TR, Yi L-X, Zhang R, Spencer J, et al. Emergence of plasmid-mediated colistin resistance mechanism MCR-1 in animals and human beings in China: a microbiological and molecular biological study. Lancet Infect Dis. 2016;16(2):161-8.

29. Haeili M, Javani A, Moradi J, Jafari Z, Feizabadi MM, Babaei E. MgrB alterations mediate colistin resistance in Klebsiella pneumoniae isolates from Iran. Front Microbiol. 2017:8:2470.

30. Cannatelli A, D'Andrea MM, Giani T, Di Pilato V, Arena F, Ambretti S, et al. In vivo emergence of colistin resistance in Klebsiella pneumoniae producing KPC-type carbapenemases mediated by insertional inactivation of the PhoQ/PhoP mgrB regulator. Antimicrob Agents Chemother. 2013;57(11):5521-6.

31. Jayol A, Poirel L, Brink A, Villegas M-V, Yilmaz M, Nordmann P. Resistance to colistin associated with a single amino acid change in protein PmrB among Klebsiella pneumoniae isolates of worldwide origin. Antimicrob Agents Chemother. 2014;58(8):4762-6.

32. Cannatelli A, Di Pilato V, Giani T, Arena F, Ambretti S, Gaibani P, et al. In vivo evolution to colistin resistance by $\mathrm{PmrB}$ sensor kinase mutation in KPCproducing Klebsiella pneumoniae is associated with low-dosage colistin treatment. Antimicrob Agents Chemother. 2014;58(8):4399-403.

33. Carattoli A, Bertini A, Villa L, Falbo V, Hopkins KL, Threlfall EJ. Identification of plasmids by PCR-based replicon typing. J Microbiol Methods. 2005;63(3):219-28.

34. Kitchel B, Rasheed JK, Patel JB, Srinivasan A, Navon-Venezia S, Carmeli Y, et al. Molecular epidemiology of KPC-producing Klebsiella pneumoniae isolates in the United States: clonal expansion of multilocus sequence type 258. Antimicrob Agents Chemother. 2009;53(8):3365-70.

35. Adamek M, Overhage J, Bathe S, Winter J, Fischer R, Schwartz T. Genotyping of environmental and clinical Stenotrophomonas maltophilia isolates and their pathogenic potential. PLoS ONE. 2011;6(11):e27615.

36. Vaez H, Sahebkar A, Khademi F. Carbapenem-resistant Klebsiella Pneumoniae in Iran: a systematic review and meta-analysis. J Chemother. 2019:31(1):1-8.

37. Codjoe FS, Donkor ES. Carbapenem resistance: a review. Med Sci. 2018;6(1):1

38. Hindler JA, Humphries RM. Colistin MIC variability by method for contemporary clinical isolates of multidrug-resistant Gram-negative bacilli. J Clin Microbiol. 2013;51(6):1678-84.

39. Paterson DL, Harris P. Colistin resistance: a major breach in our last line of defence. Lancet Infect Dis. 2016;16(2):132.

40. Marchaim D, Chopra T, Pogue JM, Perez F, Hujer AM, Rudin S, et al. Outbreak of colistin-resistant, carbapenem-resistant Klebsiella pneumoniae in metropolitan Detroit, Michigan. Antimicrob Agents Chemother. 2011:55(2):593-9.

41. Petrosillo N, Taglietti F, Granata G. Treatment options for colistin resistant Klebsiella pneumoniae: present and future. J Clin Med. 2019:8(7):934.

42. Berrazeg M, Diene S, Medjahed L, Parola P, Drissi M, Raoult D, et al. New Delhi Metallo-beta-lactamase around the world: an eReview using Google Maps. Eurosurveillance. 2014;19(20):20809.

43. Briongos-Figuero L, Gomez-Traveso T, Bachiller-Luque P, Dominguez-Gil Gonzalez M, Gómez-Nieto A, Palacios-Martín T, et al. Epidemiology, risk 
factors and comorbidity for urinary tract infections caused by extendedspectrum beta-lactamase (ESBL)-producing enterobacteria. Int J Clin Pract. 2012;66(9):891-6.

44. Rahman M, Shukla SK, Prasad KN, Ovejero CM, Pati BK, Tripathi A, et al. Prevalence and molecular characterisation of New Delhi metallo- $\beta$ lactamases NDM-1, NDM-5, NDM-6 and NDM-7 in multidrug-resistant Enterobacteriaceae from India. Int J Antimicrob Agents. 2014;44(1):30-7.

45. Bogaerts P, Verroken A, Jans B, Denis O, Glupczynski Y. Global spread of New Delhi metallo- $\beta$-lactamase 1. Lancet Infect Dis. 2010;10(12):831-2.

46. Leverstein-Van Hall MA, Stuart JC, Voets GM, Versteeg D, Tersmette T, Fluit AC. Global spread of New Delhi metallo- $\beta$-lactamase 1. Lancet Infect Dis. 2010;10(12):830-1.

47. Voulgari E, Gartzonika C, Vrioni G, Politi L, Priavali E, Levidiotou-Stefanou $\mathrm{S}$, et al. The Balkan region: NDM-1-producing Klebsiella pneumoniae ST11 clonal strain causing outbreaks in Greece. J Antimicrob Chemother. 2014;69(8):2091-7.

48. Solgi H, Badmasti F, Giske CG, Aghamohammad S, Shahcheraghi F. Molecular epidemiology of NDM-1-and OXA-48-producing Klebsiella pneumoniae in an Iranian hospital: clonal dissemination of ST11 and ST893. J Antimicrob Chemother. 2018:73(6):1517-24.

49. Markovska R, Schneider I, Ivanova D, Mitov I, Bauernfeind A. Predominance of IncL/M and IncF plasmid types among CTX-M-ESBL-producing Escherichia coliand Klebsiella pneumoniae in Bulgarian hospitals. APMIS. 2014;122(7):608-15.

50. Protonotariou E, Poulou A, Politi L, Sgouropoulos I, Metallidis S, Kachrimanidou M, et al. Hospital outbreak due to a Klebsiella pneumoniae ST147 clonal strain co-producing KPC-2 and VIM-1 carbapenemases in a tertiary teaching hospital in Northern Greece. Int J Antimicrob Agents. 2018;52(3):331-7.

51. Yu H, Qu F, Shan B, Huang B, Jia W, Chen C, et al. Detection of the mcr-1 colistin resistance gene in carbapenem-resistant Enterobacteriaceae from different hospitals in China. Antimicrob Agents Chemother. 2016;60(8):5033-5.

52. Esposito EP, Cervoni M, Bernardo M, Crivaro V, Cuccurullo S, Imperi F, et al. Molecular epidemiology and virulence profiles of colistin-resistant Klebsiella pneumoniae blood isolates from the Hospital Agency "Ospedale dei Colli", Naples, Italy. Front Microbiol. 2018;9:1463.

53. Stoesser N, Mathers AJ, Moore CE, Day NP, Crook DW. Colistin resistance gene mcr-1 and pHNSHP45 plasmid in human isolates of Escherichia coli and Klebsiella pneumoniae. Lancet Infect Dis. 2016;16(3):285-6.

54. Di Pilato V, Arena F, Tascini C, Cannatelli A, De Angelis LH, Fortunato S, et al. mcr-1.2, a new mcr variant carried on a transferable plasmid from a colistin-resistant KPC carbapenemase-producing Klebsiella pneumoniae strain of sequence type 512. Antimicrob Agents Chemother. 2016;60(9):5612-5.
55. Rapoport M, Faccone D, Pasteran F, Ceriana P, Albornoz E, Petroni A, et al. First description of mcr-1-mediated colistin resistance in human infections caused by Escherichia coli in Latin America. Antimicrob Agents Chemother. 2016;60(7):4412-3.

56. Pishnian Z, Haeili M, Feizi A. Prevalence and molecular determinants of colistin resistance among commensal Enterobacteriaceae isolated from poultry in northwest of Iran. Gut pathogens. 2019:11(1):1-8.

57. Moosavian $\mathrm{M}, \mathrm{Emam} \mathrm{N}$. The first report of emerging mobilized colistinresistance (mcr) genes and ERIC-PCR typing in Escherichia coli and Klebsiella pneumoniae clinical isolates in southwest Iran. Infect Drug Resist. 2019;12:1001.

58. Cannatelli A, Giani T, D’Andrea MM, Di Pilato V, Arena F, Conte V, et al. MgrB inactivation is a common mechanism of colistin resistance in KPCproducing Klebsiella pneumoniae of clinical origin. Antimicrob Agents Chemother. 2014;58(10):5696-703.

59. Poirel L, Jayol A, Bontron S, Villegas M-V, Ozdamar M, Türkoglu S, et al. The mgrB gene as a key target for acquired resistance to colistin in Klebsiella pneumoniae. J Antimicrob Chemother. 2014;70(1):75-80.

60. Olaitan AO, Morand S, Rolain J-M. Mechanisms of polymyxin resistance: acquired and intrinsic resistance in bacteria. Front Microbiol. 2014:5:643.

61. Cheng Y-H, Lin T-L, Pan Y-J, Wang Y-P, Lin Y-T, Wang J-T. Colistin resistance mechanisms in Klebsiella pneumoniae strains from Taiwan. Antimicrob Agents Chemother. 2015;59(5):2909-13.

62. Choi M-J, Park YK, Peck KR, Ko KS. Mutant prevention concentrations of colistin used in combination with other antimicrobial agents against Acinetobacter baumannii, Klebsiella pneumoniae and Pseudomonas aeruginosa clinical isolates. Int J Antimicrob Agents. 2014;44(5):475-6.

63. Mathur P, Veeraraghavan B, Devanga Ragupathi NK, Inbanathan FY, Khurana S, Bhardwaj N, et al. Multiple mutations in lipid-A modification pathway \& novel fosA variants in colistin-resistant Klebsiella pneumoniae. Fut Sci OA. 2018;4(07):FSO319

64. Wright MS, Suzuki Y, Jones MB, Marshall SH, Rudin SD, van Duin D, et al. Genomic and transcriptomic analyses of colistin-resistant clinical isolates of Klebsiella pneumoniae reveal multiple pathways of resistance. Antimicrob Agents Chemother. 2015;59(1):536-43.

65. Poirel L, Jayol A, Bontron S, Villegas M-V, Ozdamar M, Türkoglu S, et al. The mgrB gene as a key target for acquired resistance to colistin in Klebsiella pneumoniae. J Antimicrob Chemother. 2015;70(1):75-80.

\section{Publisher's Note}

Springer Nature remains neutral with regard to jurisdictional claims in published maps and institutional affiliations.
Ready to submit your research? Choose BMC and benefit from:

- fast, convenient online submission

- thorough peer review by experienced researchers in your field

- rapid publication on acceptance

- support for research data, including large and complex data types

- gold Open Access which fosters wider collaboration and increased citations

- maximum visibility for your research: over $100 \mathrm{M}$ website views per year

At BMC, research is always in progress.

Learn more biomedcentral.com/submissions 